\title{
Effect of E-Service Quality on Repurchase Intention: Testing the Role of E-Satisfaction as Mediator Variable
}

\author{
Veronika Trivia Lestari, Jeanne Ellyawati
}

\begin{abstract}
Recent developments in information and communication technology have contributed to tremendous economic efficiency. Companies that can take advantage of the sophistication of information and communication technology can operate more efficiently. Firm efficiency will tend to lower product prices and faster delivery time. It is expected to increase consumer satisfaction and repurchase intention. This study investigates the influence of e-service quality on repurchase intention with satisfaction as mediating variable. E-service quality was measured by five variables, namely ease of use, website design, security, personalization, and responsiveness. Good service quality tends to satisfy consumers and leads to repurchase intentions. To collect data, this study used survey design with purposive sampling method. The sample in this study are respondents who have experience in purchasing airline etickets for domestic flights within last year. To collect data, we distributed structured questionnaires to 263 respondents. To verify hypothesis, this study used descriptive statistics and hierarchical regression analysis. The results showed that $e$ satisfaction partially mediate the influence of ease of use, website design, responsiveness, and personalization on repurchase intentions. While e-satisfaction proved fully mediates the influence of security guarantees on repurchase intention.

Keywords:-e-satisfaction, e-service quality, online shopping, repurchase intention.
\end{abstract}

\section{INTRODUCTION}

In the last two decades in business world, there has been a power shifting from marketers to consumers (Ferrel \& Hartline, 2014). Competition between companies in the current economic era is more on how to find a way to meet the needs of consumers than to compete with a competitor. Changes in communication and information technology are very important in this shift. Technological change has created economic efficiency, especially in e-commerce. Internet technology becomes a powerful tool to support implementation of consumer needs. With e-commerce consumers can access directly to the company at any time, consumers do not need to spend time at store. They also

Potential sales through e-commerce is still growing. However, to achieve success, a company relies not only on attractive web display, low price or product quality, but also provides excellent service all the time. In addition, trust becomes one of the important factors in the success of online shop. Trust can eliminate consumer skepticism to buy products in online shopping. The study of online fashion

Revised Manuscript Received on July 18, 2019.

Veronika Trivia Lestari, Universitas Atma Jaya Yogyakarta

Jeanne Ellyawati, Universitas Atma Jaya Yogyakarta (j.ellyawati@uajy.ac.id) have product variety choices and get more information.

shop conducted by Windi \& Ellyawati (2015) stated that online trust significantly affects online customer purchase intention. Online shopping trust in their study is built through corporate reputation and customer relationship marketing. Another factor that affects online buying intention is ease of use.

Previous studies were conducted by Aren et al. (2013), states that the ease of use in online sales has been shown to affect purchase intention.

Excellent service can create customer satisfaction, further more consumer satisfaction can lead to repurchase intention (Ellyawati, 2017; Wen et al., 2011). Similarly, in eshopping, delivering high quality service to customers has become the primary predictor of customer e-satisfaction, and furthermore increased online purchase intention (Ribbink et al., 2004; Lee and Lin, 2005; Lau et al., 2011). In order to build consumer retention therefore companies should focus on service and create customer e-satisfaction.

In the last two years the internet user population in Indonesia increased dramatically. Based on statistical data from the Association of Indonesian Internet Service Providers (APJII, 2018) stated that in 2016 the percentage of internet users in Indonesia as much as $48 \%$, and increased sharply in $2017(54.68 \%)$ and at the end of 2018 internet users reached $60 \%$. When we look at this ratio of population to internet users, the penetration rate of internet users in Indonesia has increased every year. Thus in the future potential internet user will still continue to increase.

The prediction of tremendous growth of internet users is a promising digital market for online transactions. Online purchasing airline ticket (e-ticket) is one of the e-tailing activities that are widely used by consumers. Based on a national Indonesian daily news (www.kompas.com, 2014) consumer intention to buy airline tickets via online is between $25 \%$ and $30 \%$. They booked tickets through travel agents $(65 \%)$ and call centers $(5 \%)$. E-ticket sales in Indonesia are still low compared to offline sales. This can be occurred because consumers do not understand the procedure of buying airline tickets via online or there is no trust to online companies and other factors. This makes consumers do not interested in purchasing through website. With research setting of online shopping and research objective of Indonesia domestic airline ticket, the study tries to investigate the effect of e-service quality on esatisfaction, and in turn on repurchase intention. It will also investigate the role of e-satisfaction as mediating variable

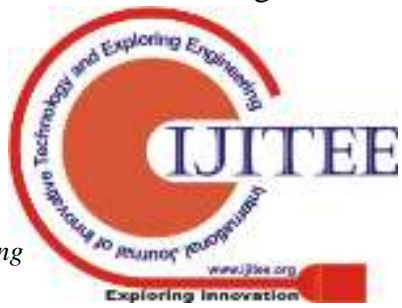




\section{EFFECT OF E-SERVICE QUALITY ON REPURCHASE INTENTION: TESTING THE ROLE OF E- SATISFACTION AS MEDIATOR VARIABLE}

that relates between e-service quality and repurchase intention. Is e-satisfaction fully mediate the relationship between e-service quality and repurchase intention, partially or even no mediation at all.

\section{THEORITICAL BACKGROUND AND HYPOTHESIS DEVELOPMENT}

Electronic services quality according to Santos (2003) is the overall evaluation and judgment concerning excellence and quality in service delivery on online transactions. Parasuraman et al. (2005) stated that electronic service quality is a facility in a website designed to be effective and efficient in making online purchases. Study conducted by Lee and Lin (2005) investigated dimensions of electronic service quality based on SERVQUAL model in the context of online shopping and its effect on overall service quality, customer satisfaction and purchase intention. This study is also an adaptation of the SERVQUAL model with five observed variable consisting of ease of use, website design, security, responsiveness and personalization.

Customer satisfaction is the level at which the product's performance is fit with customer expectations. When the product's performance does not meet expectations, the customer will be disappointed and leads to dissatisfaction. When product's performance exceeds expectations, the customer will satisfy (Kotler and Armstrong, 2018; Ellyawati et al., 2017). Hellier et al. (2003) defines customer satisfaction as the level of overall pleasure or satisfaction perceived by consumers, resulting from the ability of services in meeting customer desires, expectations, and needs in relation to the services provided. Anderson and Srinivasan (2003) defined e-satisfaction as a feeling of pleasure that consumers feel in relation with previous buying experiences in online shopping context. Studies in the aviation industry, explain that passenger satisfaction plays an important role in measuring service quality and the possibility of customers continuing to use the service in the future (Archana and Subha, 2012). In addition, Lau et al. (2011) in their study about e-ticket in online buying in Malaysia, also found that the electronic service quality variable had a positive effect on customer satisfaction. When customer perceived e-service quality increased, it will lead to customer satisfaction.

According to Shih (2010) purchase intention is the behavior of consumers who are willing to buy a product or service and even willing to encourage friends and relatives to buy the product or service. Whereas repurchase intention is an individual's judgment about buying services again from the same company by considering the current situation or possible situation (Hellier et al., 2003). In the literature stated that customer satisfaction is antecedents of purchase intention. It means that consumers who experience satisfaction will lead to purchase intentions. Thus the company must always maintain good relationships with consumers that exist today. It is expected that consumers who experience satisfaction will increase purchase intention/ repurchase intention (Chang et al., 2014; Azam et al., 2012).

Based on these argumentations, hypotheses proposed: H1: Ease of use effects positively on repurchase intention
H2: Website design effects positively on repurchase intention.

H3: Security effects positively on repurchase intention.

H4: Responsiveness effects positively on repurchase intention.

H5: Personalization effects positively on repurchase intention.

H6: e-satisfaction mediates the relation between ease of use and repurchase intention

H7: Website design effects positively one-satisfaction

H8: Security effects positively on e-satisfaction

H9: Responsiveness effects positively on e-satisfaction

H10: Personalization effects positively on e-satisfaction

\section{METHODOLOGY}

\section{A. Sample and data collection}

The research setting in this study is online buying airline tickets. Since the population is unknown, therefore this study used a non-probability sampling method, namely purposive sampling. Sample who are allowed to be selected as respondents in this study are those who aged 20 years and over and have purchased online airline tickets for domestic flights within last year. The study design was a cross sectional survey. Data were collected by distributing questionnaires to respondents through google.doc application. The number of respondents collected was 263 respondents. respondents.

\section{B. Research Procedure}

The questionnaire in this study was divided into two parts. The first part contains demographics characteristics to describe respondent profile. The second part contains a measurement of research variables used to verify hypothesis. Observed variables are measured using research instruments developed by previous studies with modified as needed. Service quality variables were measured using variables: website design, security assurance, responsiveness, and personalization that were adapted from study conducted by Lau et al. (2011). While e-satisfaction was measured using the scale developed by Ribbink et al. (2004) and repurchase intention (Lu et al., 2012).

The questionnaire was translated into Indonesian by a professional translator and then content validity was carried out to ensure that the content of the questionnaire was in accordance with the original meaning. The next activity is to do face validity to eliminate written errors and incomprehension of the meaning of the sentence in the questionnaire. After several improvements and adaptation to the situation and conditions in Indonesia, the research instrument was then typed in google.doc application format and ready to be distributed to 30 respondents for the purpose of validity and reliability test.

\section{Measurement}

All of observed variables in this study were measured using a five-point Likert scale. The score interval is between 1 and 5, where score 1 for a strongly disagree and a score 5 
for strongly agree. All observed variables in this study were measured using multi item indicators. Descriptive statistics analysis is used to describe respondent profile, while multiple regression is used to verify hypothesis testing. We used hierarchical regression analysis to verify mediation test, and it is carried out based on theory of Baron and Kenny (1986) and Zhao et al. (2010). We used SPSS for Windows version 15.0 software to process the data.

In order to get a good quality of data, the research instruments must be tested with validity and reliability tests before distributed to all respondents. Validity test is concerned with the accuracy and precision of a concept that will be measured (Sekaran \& Bougie, 2016). The validity of the instruments was tested with Pearson Correlations and 95\% level of confident. The research instrument is stated valid, when the loading factor is greater than or equal to 0.6 (Hair et al., 2014). Validity test resulted in this study can be known from corrected item to total correlation value from If the $r$-count is greater than $r$-table (by using $\alpha=5 \%$ ), therefore the items or indicators used in this study is considered valid and vice versa ( $r$-table value is 0.361 ).

According to Sekaran and Bougie (2016) reliability includes both stability measurement and internal consistency. A measure is considered reliable if it provides consistent results (Cooper and Schindler, 2008). Reliability testing is only processed on items that have passed the validity test. The limit value used to assess an acceptable level of reliability is using Cronbach's Alpha value more than 0.7 (Sekaran and Bougie, 2016).

From data processing, we found all of research instruments have r-values greater than r-table (0.361). While Cronbach's Alpha coefficient for all constructs shows values more than 0.7 . Thus it can be concluded that all of the research instruments are valid and reliable.

\section{RESULT}

\section{A. Descriptive Statistics}

From 263 selected respondents with criteria that they have purchased online airline tickets during last twelve months, most of them were females $(60.84 \%)$ and aged between 20 to 30 years $(82.89 \%)$. They are young people who are undergraduate students with average monthly income between Rp. 1,500,000 to Rp. 3,000,000 and have experience in purchasing online tickets twice in a year. Most of them used website www.traveloka.com and bought AirAsia airline tickets. Table 2 provides the summary of the characteristics of respondents.

\section{B. Hypothesis Testing}

This study used hierarchical regression model to verify hypothesis with referring to Baron and Kenny theory (1986) and Zhao (2010), and the data were processed using SPSS Ver.25.

\section{Effect of ease of use on repurchase intention}

Based on regression analysis, ease of use directly effects positively and significantly on repurchase intention $(\beta=+$ 0.668 ; $\mathrm{p}$-value $<0.05$ ). While the R-square (adjusted) shows the value of 0.444 . This can be interpreted that ease of use variable can explain $44.4 \%$ on repurchase intention, while each research instrument by comparing $r$-count with $r$-table.

$55.6 \%$ is explained by other variables not include in the model. It means that if the level of ease of use increases then there is a tendency that repurchase intention will also increase. Thus hypothesis H1 is supported.

\section{E-satisfaction mediates between ease of use and repurchase} intention.

The statistical test results showed significant effect of ease of use on e-satisfaction $(\beta=+0.711$; p-value $<0.05)$. While the ease of use variable also has a significant effect on repurchase intention. E-satisfaction variables have a significant effect on purchase intention $(\beta=+0.455$; $p$-value $<0.05$ ). Based on regression results, beta coefficient value of ease of use on repurchase intention after controlling esatisfaction is reduced but still significant at +0.345 . It is smaller than beta coefficient of ease of use variable on repurchase intention without controlling e-satisfaction variables $(\beta=+0,668)$. Referring to Baron and Kenny (1986) model, the results can be categorized into partial mediation. Thus it can be concluded that e-satisfaction mediates the relationship between ease of use and repurchase intention. Therefore, hypothesis H6 is supported.

\section{Effect of web design on repurchase intention}

Based on regression analysis, web design directly effects positively and significantly on repurchase intention $(\beta=+$ 0.560 ; p-value $<0.05$ ). While the R-square (adjusted) shows the value of 0.311 . This can be interpreted that web design variable can explain $31.1 \%$ on repurchase intention, while $68.9 \%$ is explained by other variables not include in the model. It means that if the level of websites design increases then there is a tendency that repurchase intention will also increase. Thus hypothesis $\mathrm{H} 2$ is supported.

E-satisfaction mediates between website design and repurchase intention.

The regression test results showed significant effect of web design on e-satisfaction $(\beta=+0,653$; $p$-value $<0.05)$. Esatisfaction effect on repurchase intention significantly $(\beta=$ $+0,581$; p-value $<0.05$ ). Based on regression results, beta coefficient value of web design on repurchase intention after controlling e-satisfaction is reduced but still significant at +0.181 . It is smaller than beta coefficient of web design on repurchase intention without controlling e-satisfaction variables $(\beta=+0,560)$. Referring to Baron and Kenny (1986) model, the results can be categorized into partial mediation. Thus it can be concluded that e-satisfaction mediates the relationship between web site design and repurchase intention. Therefore, hypothesis $\mathrm{H} 7$ is supported.

Effect of security assurance on repurchase intention Based on regression analysis, security directly effects positive and significant on repurchase intention $(\beta=+$ 0.394; p-value <0.05). While the R-square (adjusted) shows the value of 0.152 . This can be interpreted that security assurance variable can explain $15.2 \%$ on repurchase intention, while $84.8 \%$ is explained by other variables not include in the model. It means that if the level of security assurance increases then there is a tendency that repurchase 


\section{EFFECT OF E-SERVICE QUALITY ON REPURCHASE INTENTION: TESTING THE ROLE OF E- SATISFACTION AS MEDIATOR VARIABLE}

intention will also increase. Thus hypothesis H3 is supported.

\section{E-satisfaction mediates between security and repurchase intention.}

The regression test results showed significant effect of security assurance on e-satisfaction $(\beta=+0.462$; p-value $<0.05)$. E-satisfaction effect significantly on purchase intention $(\beta=+0.090$; $p$-value $>0.05)$. Based on regression results, beta coefficient value of security assurance on repurchase intention after controlling e-satisfaction is not significant. Referring to Baron and Kenny (1986) model, if independent variable does not influence directly on security assurance variable after controlling for the mediator variable it can be stated as perfect or complete mediation. Therefore, hypothesis $\mathrm{H} 8$ is supported.

\section{Effect of responsiveness on repurchase intention}

Based on regression analysis, responsiveness directly effects positively and significantly on repurchase intention $(\beta=+0.586 ; p$-value $<0.05)$. While the R-square (adjusted) shows the value of 0.341 . This can be interpreted that responsiveness variable can explain $34.1 \%$ on repurchase intention, while $65.9 \%$ is explained by other variables not include in the model. It means that if the level of responsiveness increases then there is a tendency that repurchase intention will also increase. Thus hypothesis H4 is supported.

\section{E-satisfaction mediates between responsiveness and repurchase intention.}

The regression test results showed significant effect of responsiveness on e-satisfaction $(\beta=+0,626$; $\mathrm{p}$-value $<0.05)$. E-satisfaction significantly effect on purchase intention $(\beta=+0,547$; $p$-value $<0.05)$. Based on regression results, beta coefficient value of responsiveness on repurchase intention after controlling e-satisfaction is reduced but still significant at +0.244 . It is smaller than beta coefficient of responsiveness on repurchase intention without controlling e-satisfaction variables $(\beta=+0,586)$. Referring to Baron and Kenny (1986) model, the results can be categorized into partial mediation. Thus it can be concluded that e-satisfaction mediates the relationship between responsiveness and repurchase intention. Therefore, hypothesis H9 is supported.

\section{Effect of personalization on repurchase intention}

Based on regression analysis, personalization directly effects positively and significantly on repurchase intention $(\beta=+0,561 ; p$-value $<0.05)$. While the R-square (adjusted) shows the value of 0.312 . This can be interpreted that personalization variable can explain $31.2 \%$ on repurchase intention, while $68.8 \%$ is explained by other variables not include in the model. It means that if the level of personalization increases then there is a tendency that repurchase intention will also increase. Thus hypothesis 5 is

The regression test results showed significant effect of personalization on e-satisfaction $(\beta=+0,663$; p-value $<0.05)$. While the personalization directly effects significantly on repurchase intention $(\beta=+0.561$; $p$-value $<0.05)$. E-satisfaction variables have a significant effect on supported.

repurchase intention $(\beta=+0,584$; $p$-value $<0.05)$. Based on regression results, beta coefficient value of personalization on repurchase intention after controlling e-satisfaction is reduced but still significant at +0.174 . It is smaller than beta coefficient of personalization variable on repurchase intention without controlling e-satisfaction variables $(\beta=+0,561)$. Referring to Baron and Kenny (1986) model, the results can be categorized into partial mediation. Thus it can be concluded that e-satisfaction mediates the relationship between personalization and repurchase intention. Thus hypothesis H10 is supported.

\section{CONCLUSION}

This study proves that online service quality (ease of use, website design, security assurance, responsiveness and personalization) affects repurchase intention and satisfaction. Only e-satisfaction is proven to mediate perfectly between security assurance and repurchase intentions.

From the result of this study, we suggest that to increase customer repurchase intention, online service provider should develop a business by creating a good quality of company website. Some aspects of the quality website services that need to put more attention, include: creating websites that really user friendly. This means that consumers can easily access and operate websites that are used to make online purchase transactions. Website must be easy to read, like font, size and color combination.

Service interfaces must be visually attractive, and the system neatly organized. Another thing to note is that companies should always improve security in the payment method, because financial crime is getting more increase. Companies also have to train staff to quickly help to solve the problems of each consumer who needs help. To complete the quality of services, personalization also needs to be considered, for example companies can recommend according to the needs of each customer.

\section{REFERENCES}

1. R. E. Anderson and S. S. Srinivasan, "E-satisfaction and ELoyalty: A Contigency Framework," Psychology and Marketing, 20(2), pp. 123-138, 2003

2. R. Archana and M. V. Subha, "A Study On Service Quality and Passenger Satisfaction On Indian Airlines," International Journal of Multidisciplinary Research, 2 (2), pp. 50-63, 2012

3. S. Aren, M. Guzel, E. Kabadayi, and L. Alpkan, "Factors Affecting Repurchase Intention to Shop at the Same Website," Social and Behavioral Sciences, 99(1), pp. 536-544, 2013.

4. APJII (Asosiasi Penyedia Jasa Internet Indonesia), "Penetrasi dan Perilaku Pengguna Internet Indonesia Survey 2018," APJII, downloaded from https://.apjii.or.id, 6 May 2019

5. A. Azam, F. Qiang., and M. I. Abdullah, "E-satisfaction in Business to Consumer Electronic Commerce," The Business and Management Review, 13(1), pp. 18-26, 2012

6. R. M. Baron, and D. A. Kenny, "The Moderator-Mediator Variable Distinction in Social Psychological Research: Conceptual, Strategic, and Statistical Considerations," Journal of Personality and Social Psychology, 51(6), pp. 1173-1182, 1986.

7. S. C. Chang, P. Y. Chou, and L. W. Chien, " Evaluation Of 
Satisfaction And Repurchase Intention In Online Food GroupBuying, Using Taiwan As An Example," British Food Journal, 116(1), pp.44-61, 2014.

8. D. R. Cooper and P. Schindler, "Business Research Methods," 10th ed., Singapore: McGraw-Hill, 2008

9. J. Ellyawati, "Double Deviation Investigation of Perceived Service Recovery Justice: A Study On The Indonesian Airline Industry," Journal of Applied Business Research, Vol. 33(6), pp 1263-1272, 2017.

10. O. C. Ferrel and M. O. Hartline, "Marketing Strategy, Text and Cases," 6th ed., Mason, USA: South Western Cengage Learning, 2014.

11. J. F. Hair Jr., W. C. Black, B. J. Babin, R. E. Anderson, and R. J. Tatham, "Multivariate Data Analysis," 7th ed., Pearson Education Limited: Edinburgh Gate, 2014.

12. P. K. Hellier, G. M. Geursen, R. A. Carr, and J. A. Rickard, "Customer Repurchase Intention: A General Structural Equation Model," European Journal of Marketing, 37(11), pp. 1762-1800, 2003.

13. P. Kotler, and G. Armstrong, "Principles of Marketing," 17th ed., Harlow, UK: Pearson Education Limited, 2018.

14. T.C. Lau, C. L. Kwek, and H. P. Tan, "Airline e-Ticketing Service: How e-Service Quality and Cusomer Satisfaction Impacted Purchase Intention," International Business Management, 5(4), pp. 200-208, 2011.

15. G. Lee, and H. Lin, "Customer Perceptions of E-Service Quality In Online Shopping," International Journal of Retail and Distribution Management, 33(2), pp. 161-176, 2005.

16. Y. Lu, Y. Lu, and B. Wang, "Effects of Dissatisfaction on Customer Repurchase Decisions In E-Commerce-An Emotion-Based Perspective," Journal of Electronic Commerce Research, 13(3), pp. 224-225, 2012.

17. A. Parasuraman, V. A. Zeithaml, and A. Malhotra, "E-SQUAL: A Multiple -Item Scale for Assesing Electronic Service Quality," Journal of Service Research, 7(10), pp. 121, 2005.

18. D. Ribbink, A. C. R. Van Riel, V. Liljander, and S. Streukens, "Comfort Your Online Customer: Quality, Trust, and Loyalty On The Internet," Managing Service Quality, 14(6), pp. 446-456, 2004.

19. J. Santos, "E-Service Quality: A Model Of Virtual Service Quality Dimensions," Management Service Quality, 13(3), pp. 233-46, 2003.

20. U. Sekaran, and R. Bougie, "Research Methods for Business," 6th Edition. United Kingdom: John Wiley \& Son Ltd, 2013.

21. T. Shih, "Comparative Analysis of Marketing Strategies For Manufacturers And Retailers Brands," International Journal of Electric Business Management, 8(1) pp. 56- 67, 2010.

22. C. Wen, V. R. Prybutok, and C. Xu, "An Integrated Model For Customer Online Repurchase Intention," The Journal of Computer Information Systems, 52 (1), pp.14-23, 2011.

23. Windi and J. Ellyawati, "Trust, Antecedent and Consequence in Online Shopping Context: Testing The Role of E-WOM as Moderating Effect," International Journal of Management and Applied Science,

24. Vol. 1 (5): 41-45, June 2015. X. Zhao, J. G. Lynch JR, and Q Chen, "Reconsidering Baron and Kenny: Myths and Thruths about Mediation Analysis," Journal of Consumer Research, 37(1), pp. 197-206, 2010.

25. www.kompas.com, 2014 (downloaded on 14 March 2019) 